\title{
TK2 wt Allele
}

National Cancer Institute

\section{Source}

National Cancer Institute. TK2 wt Allele. NCI Thesaurus. Code C51332.

Human TK2 wild-type allele is located within 16q22-q23.1 and is approximately $40 \mathrm{~kb}$ in length. This allele, which encodes thymidine kinase 2 , mitochondrial protein, is involved in the mitochondrial salvage pathway and plays a role in the phosphorylation of thymidine, deoxycytidine, and deoxyuridine. Certain allelic variants of the TK2 gene are associated with myopathic mitochondrial DNA depletion syndrome. 